\title{
DNA restriction fingerprint analysis of the soil bacterium Azospirillum
}

\author{
Luciana Giovannetti, ${ }^{1 *}$ Stefano Ventura, ${ }^{1}$ Marco Bazzicalupo, ${ }^{2}$ Renato Fani $^{2}$ and \\ RICCARDO MATERASSI ${ }^{1}$
}

${ }^{1}$ Istituto di Microbiologia Agraria e Tecnica, University of Florence, and Centro di Studio dei Microrganismi Autotrofi, CNR, Piazzale delle Cascine 27, 50144 Firenze, Italy

${ }^{2}$ Dipartimento di Biologia Animale e Genetica, University of Florence, via Romana 17, 50125 Firenze, Italy

(Received 2 October 1989; revised 16 January 1990; accepted 29 January 1990)

\begin{abstract}
Total DNAs of 18 strains of Azospirillum from different sources and geographical areas were compared by restriction endonuclease pattern analysis. Fragments obtained with HindIII or BglII were separated by PAGE and stained with silver nitrate. Each strain possessed a unique and reproducible fingerprint with each enzyme, thereby facilitating strain recognition. UPGMA analysis recovered clusters of band patterns that were compared to the distribution of species within the genus Azospirillum.
\end{abstract}

\section{Introduction}

Bacteria of the genus Azospirillum are capable of nitrogen fixation under microaerophilic conditions. Interest in this genus has increased since Döbereiner \& Day (1975) demonstrated its association with the roots of grasses, including important cereals like maize and wheat. Four species of Azospirillum have been described: A. amazonense, $A$. brasilense, $A$. halopraeferens and $A$. lipoferum (Krieg \& Döbereiner, 1984; Reinhold et al., 1987); these species were established on the basis of morphological, nutritional, physiological and biochemical characters as well as by determining the nucleic acid relatedness of many isolates.

One of the main objectives of research on Azospirillum is to obtain strains that could be used as biological fertilizers (Okon, 1985); for this reason and due to their widespread occurrence in tropical, temperate and cold soils (Döbereiner \& Day, 1975; Haahtela et al., 1981; Lamm \& Neyra, 1981), hundreds of strains of azospirilla have been isolated in different countries. This raises the problem of their accurate identification; moreover, strains used as inoculants need to be traced and detected in soil in order to evaluate their effect on plant yield. Routine identification of Azospirillum usually depends on cultural and morphological criteria; however, these techniques do not allow strains to be distinguished from each other and sometimes clear attribution to a species is not easy.

In recent years, restriction endonuclease analysis of the genome has proved a useful tool in the differentiation of viruses (Skare et al., 1975; Chowdhury et al., 1986) and bacteria (Mielenz et al., 1979; Bjorvatn et al., 1984; Dobritsa, 1985; Grothues \& Tümmler, 1987). Results obtained so far with diverse genera indicate that this technique is highly reliable and easy to perform on a large number of isolates (Kristiansen et al., 1985; Allardet-Servent et al., 1988; Peterson \& De La Maza, 1988). Few reports deal with computer-assisted numerical analysis of restriction fingerprints (Hookey et al., 1985; Sorensen et al., 1985). In the present work 18 strains of Azospirillum, representing the four established species and unclassified strains, were analysed.

\section{Methods}

Bacterial strains and growth conditions. The strains used, and their origins, are listed in Table 1. Strains of Azospirillum brasilense and $A$. lipoferum and incompletely identified strains from Italian soils were grown in Oxoid Antibiotic medium no. 3, strains of A. amazonense in Nutrient Broth (Difco) at pH 6.5 and $A$. halopraeferens Au5 in SM medium (Reinhold et al., 1985) supplemented with $0.25 \% \mathrm{NaCl}$ and adjusted to $\mathrm{pH} 7 \cdot 2$. Cultures were incubated at $35^{\circ} \mathrm{C}$ (Azospirillum $\mathrm{sp}$., $A$. brasilense, $A$. lipoferum and $A$. amazonense) or at $41^{\circ} \mathrm{C}(A$. halopraeferens) and shaken vigorously.

Preparation of total DNA. Cells were harvested in the early stationary phase, washed once with TEN buffer $(10 \mathrm{mM}$-Tris/HCl, 1 mM-EDTA, $10 \mathrm{~mm}-\mathrm{NaCl}, \mathrm{pH} 8)$ and stored at $-20^{\circ} \mathrm{C}$ until needed. Organic solvents for cell extraction were prepared according to Maniatis et al. (1982). Cells suspended in TEN were lysed by adding SDS and proteinase $\mathrm{K}$ to final concentrations of $5 \mathrm{mg} \mathrm{ml}^{-1}$ and $50 \mu \mathrm{g} \mathrm{ml}^{-1}$ respectively. The $\mathrm{NaCl}$ concentration was raised to $300 \mathrm{mM}$ and the lysate extracted twice with phenol/chloroform $(1: 1, \mathrm{v} / \mathrm{v})$ and twice with chloroform. DNA was precipitated with 2 vols cold ethanol, collected with a glass rod and resuspended in TEN. RNA was 

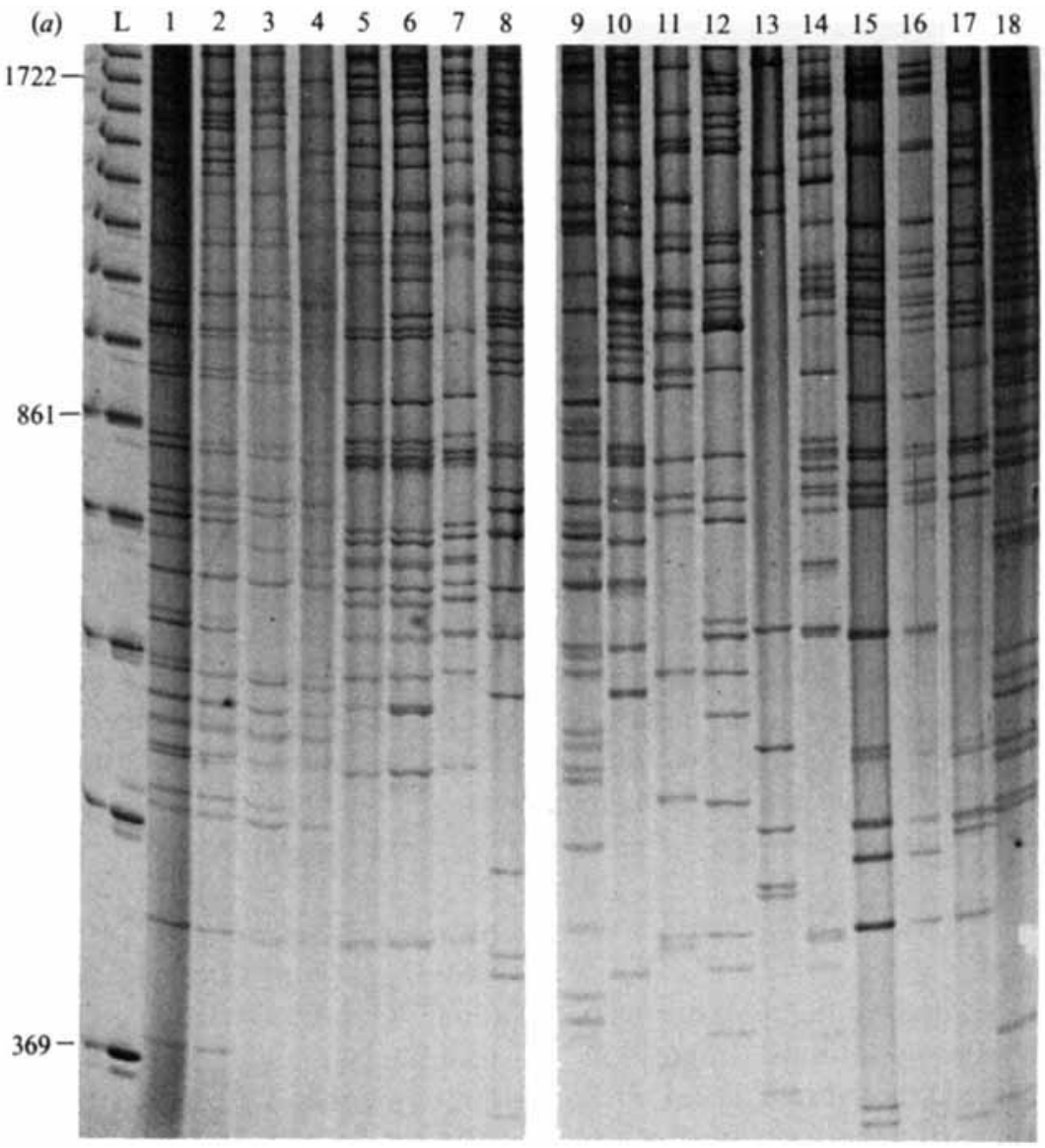

Fig. 1. (continued on facing page). SDS-PAGE profiles of Azospirillum total DNAs digested with restriction endonucleases HindIII (a) or $B g l$ II $(b)$. The strains are designated by the reference numbers listed in Table 1. Lanes L contain BRL 123 bp DNA Ladder $(a)$ or BRL 1 kb DNA Ladder $(b)$.

Table 1. Azospirillum strains used

\begin{tabular}{|c|c|c|c|c|}
\hline Ref.* & Species & Strain & Source & Received from $\dagger$ \\
\hline 5 & A. brasilense & Sp6 & Tillandsia, Italy & F. Favilli \\
\hline 6 & A. brasilense & DSM $1690 \ddagger$ & Digitaria, Brazil & DSM \\
\hline 7 & A. brasilense & $\mathrm{Cd}$ & Cynodon dactylon, USA & J. Döbereiner \\
\hline 10 & A. brasilense & F14 & Wheat, Italy & F: Favilli \\
\hline 14 & A. lipoferum & Sp242 & Maize, Brazil & \\
\hline 8 & A. lipoferum & Col5 & Hyparrhenia rufa, Colombia & J. Döbereiner \\
\hline 9 & A. lipoferum & SpBr17 & Maize, Brazil & \\
\hline 15 & A. amazonense & DSM 2787 & Digitaria decumbens, Brazil & DSM \\
\hline 16 & A. amazonense & Y1 & Digitaria decumbens, Brazil & \\
\hline 17 & A. amazonense & $\mathbf{Y} 2$ & Unknown, Brazil & \\
\hline 18 & A. amazonense & Y6 & Pennisetum purpureum, Brazil & A. Hartmann \\
\hline 13 & A. halopraeferens & Au5 & Leptochloa fusca, Pakistan & \\
\hline 1 & Azospirillum sp. § & $\mathrm{T} 1$ & Tobacco, Italy & \\
\hline 2 & Azospirillum sp. § & $\mathbf{T} 2$ & Tobacco, Italy & \\
\hline 3 & Azospirillum sp. § & T5 & Tobacco, Italy & F Favilli \\
\hline 4 & Azospirillum $\mathrm{sp} . \S$ & T8 & Tobacco, Italy & F. Favilli \\
\hline 11 & Azospirillum sp. $\S$ & M6 & Maize, Italy & \\
\hline 12 & Azospirillum sp. § & M1 & Maize, Italy & \\
\hline
\end{tabular}

* Reference number in Fig. 1.

†F. Favilli, Istituto di Microbiologia Agraria, Florence, Italy; DSM, Deutsche Sammlung von Mikroorganismen, Braunschweig, FRG; J. Döbereiner, EMBRAPA-PNPBS, Seropedica, Rio de Janeiro, Brazil; A. Hartmann, GSF Institut für Bodenökologie, Neuherberg, München, FRG.

$\ddagger$ This strain is the same as strain $\mathrm{Sp} 7$ isolated by $\mathrm{J}$. Döbereiner.

$\S$ These strains could not be assigned to any of the four described species by following species descriptions (Krieg \& Döbereiner, 1984; Reinhold et al., 1987) and the recommendations of Döbereiner (1987) and Döbereiner \& Pedrosa (1987) for the identification of azospirilla. 


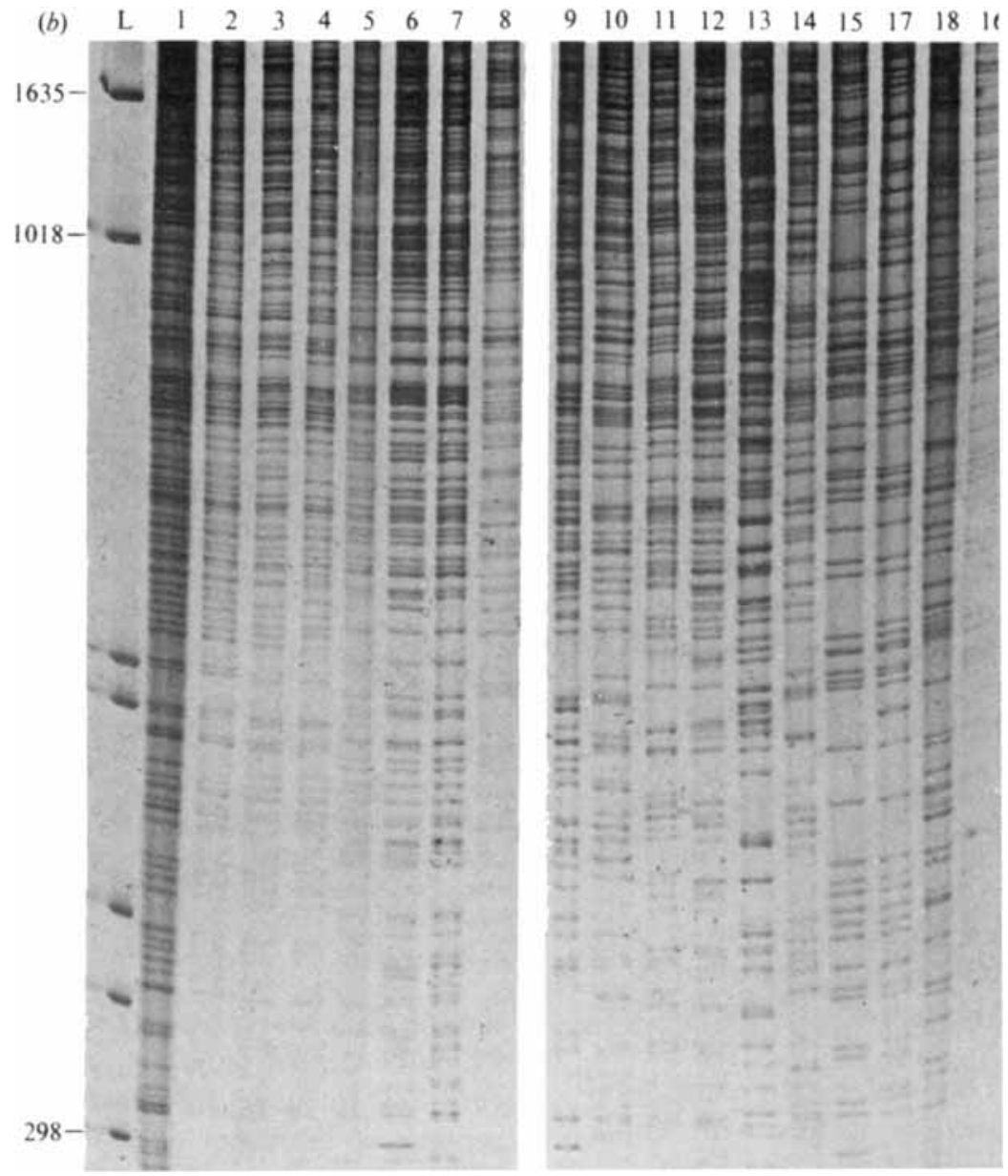

Fig. 1 (contd.)

hydrolysed with $50 \mu \mathrm{g}$ RNAase $\mathrm{A} \mathrm{ml}^{-1}$ and 3 units RNAase $\mathrm{T}_{1} \mathrm{ml}^{-1}$. The DNA was then extracted once with phenol/chloroform $(1: 1, \mathrm{v} / \mathrm{v})$ and twice with chloroform, precipitated with cold ethanol, collected with a glass rod and resuspended in TE buffer $(10 \mathrm{mM}$-Tris/ $\mathrm{HCl}, 1 \mathrm{mM}-$ EDTA, pH 8). DNA purity and concentration were checked spectrophotometrically following Maniatis et al. (1982).

Digestion of DNA. Restriction endonucleases were purchased from Boehringer Mannheim Biochemicals. Ten micrograms of DNA were completely digested with 20 units of enzyme by incubating the mixture at $37^{\circ} \mathrm{C}$ overnight, as recommended by the supplier.

SDS-PAGE. DNA digests were loaded on a vertical discontinuous $7.5 \%(w / v)$ acrylamide gel according to Laemmli (1970) and run at $17 \mathrm{~mA}$ for $17 \mathrm{~h}$ ( $19 \mathrm{~h}$ when running HindIII fragments). BRL $1 \mathrm{~kb}$ DNA Ladder or BRL 123 bp DNA Ladder were added as markers. The running gel was $22 \mathrm{~cm}$ long and $1.5 \mathrm{~mm}$ thick.

Gels were fixed and washed by soaking and gently shaking for $30 \mathrm{~min}$ in each of the following solutions: $50 \%$ ethanol $/ 10 \%$ acetic acid; $25 \%$ ethanol $/ 10 \%$ acetic acid; $10 \%$ ethanol $/ 0.5 \%$ acetic acid (all $\%$ values are $\mathrm{v} / \mathrm{v}$ ). They were then shaken for $2 \mathrm{~h}$ in silver nitrate solution $\left(1.9 \mathrm{~g}^{-1}\right)$, rinsed with distilled water and developed with formaldehyde $\left(7.5 \mathrm{~g} \mathrm{l}^{-1}\right)$ in $0.75 \mathrm{M}$-sodium hydroxide until the bands reached the desired density. Better contrast was achieved by treating the gels for $1 \mathrm{~h}$ with sodium carbonate $\left(7.5 \mathrm{~g} \mathrm{t}^{-1}\right)$.
Restriction pattern analysis. Silver-stained gels were scanned with an LKB Ultroscan II laser densitometer connected to an Olivetti M240 personal computer. Integration and peak detection were performed with LKB $2400 \mathrm{GelScan}$ XL program. Only band positions were taken into account, irrespective of any difference in density. Each band was defined by its starting and ending points and its peak position given by the INTEGRATE procedure with the GAUSSIAN and VALLEY options of the 2400 GelScan XL program. A dedicated program written in dBASE IV was used to rescale the peak positions, to compare band patterns and to calculate similarity coefficients. Two distant evident homologous bands present in each lane were used as internal standards to correct for the 'smiling' effect: common values were given to each set of homologous band peaks and the integration results of each trace were rescaled on these new values. The number of bands at coincident positions was obtained from pairwise comparisons of rescaled traces: when a peak value of a band in a trace was included between the values of the starting and ending points of a band in the other trace, then those two bands were taken to have coincident positions (i.e. to be homologous). A tolerance value $(0.1 \%$ of running gel length) was applied to either side of each band to compensate for misalignment of homologous bands due to technical imperfections (Hood et al., 1988). Similarity between each pair of strains was calculated as the Dice coefficient, $S_{\mathrm{D}}$ : the ratio of twice the number of bands common to their patterns, to the sum of all bands in the two patterns. Strains were clustered by the UPGMA method (Sneath \& Sokal, 1973) using the CLUSTER and TREE procedures of the SAS package (SAS Institute Inc., 1987). 


\section{Results and Discussion}

\section{Choice of restriction endonucleases and reproducibility of} the method

DNA of 18 strains of Azospirillum from different sources and geographical areas (Table 1) was analysed by SDSPAGE of the fragments obtained after digestion of total DNA with restriction endonucleases. SDS-PAGE was chosen as the separation technique because it offered better resolution than agarose gel electrophoresis, thereby enabling sharp separation of the low-molecular-mass nucleic acid fragments. Fragments were stained using the highly sensitive silver nitrate method (Goldman \& Merril, 1982). Digestion of total bacterial DNA with restriction endonucleases that recognize $6 \mathrm{bp}$ sites provides a wide range of fragment sizes. The smaller fragments, between 300 and $1700 \mathrm{bp}$, that were readily separated with the highest resolution, were chosen as representative fingerprints of each bacterial strain. Restriction endonucleases BanII, HindIII, EcoRI, EcoRV, BglII, DraI, HpaI, KpnI, PstI, XbaI and ClaI were tested with total DNA of $A$. brasilense strain $\mathrm{Cd}$. Endonucleases $\mathrm{HindIII}$ and $B g l \mathrm{II}$ were found to yield, in the selected size range, a number and a distribution of fragments suitable for reliable analysis with the GelScan program.

The electropherograms obtained by digesting total DNA from the 18 Azospirillum strains with either HindIII or BglII are shown in Fig. $1(a)$ and $(b)$, respectively. These show that, with both enzymes, each strain possesses a unique restriction pattern. In replicate experiments, using DNA obtained in separate extractions, each of the patterns was shown to be completely reproducible. The type strain of $A$. amazonense, obtained from two sources, A. Hartmann (strain Y1; ref. no. 16) and the DSM (DSM 2787; ref. no 15) maintained the same pattern even after repeated subculturing in separate laboratories (Fig. $1 a, b$ ). A spontaneous rifampicin-resistant mutant of $A$. brasilense Sp6 remained unaltered in its banding pattern (data not shown). The restriction pattern of total DNA thus constituted a unique fingerprint of each organism and was considered suitable for the reliable recognition of strains.

\section{Restriction pattern analysis}

Digestion with HindIII gave fewer bands than digestion with BglII. The gel with HindIII digests was analysed by scanning densitometry in the region from 370 to $1700 \mathrm{bp}$ and the gel with $B g / \mathrm{II}$ digests from 300 to $1300 \mathrm{bp}$. The selected intervals contained between 47 and 92 DNA bands per strain in the BglII gel, and between 24 and 36 bands per strain in the HindIII gel. The exception was

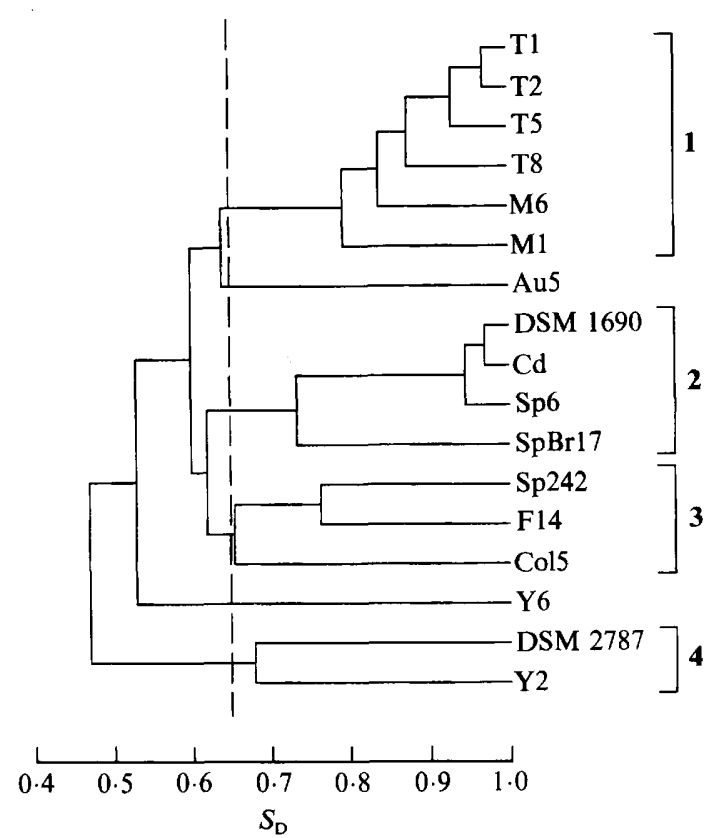

Fig. 2. Dendrogram based on UPGMA clustering of the $S_{\mathrm{D}}$ matrix obtained from $B g I I I$ restriction pattern analysis. Square brackets identify the clusters obtained with a cut-off value of 0.65 (dashed line).

the HindIII electropherogram of strain Au5 (ref. no. 13), which contained only eight bands, indicating either a very low frequency of HindIII restriction sites in its genome, or inhibition of hydrolysis due to methylation. The latter occurrence would limit the usefulness of the method for the study of the relationship among strains, but should not interfere with the identification of a single strain. The matrix of $S_{\mathrm{D}}$ coefficients obtained from the analyses of the two sets of restriction patterns showed lower values for HindIII digestions than for $B g l \mathrm{II}$ digestions (not shown). This difference, which cannot be easily explained, indicates that the calculated $S_{\mathrm{D}}$ between strains is affected by the choice of the restriction enzyme. This suggests that caution is required in the screening and in the selection of the restriction enzyme in order to avoid misinterpretation of data. However, in the present case, UPGMA clustering (see below) applied to both sets of data gave almost correspondent groupings (dendrogram of $H$ indIII matrix not shown). Fig. 2 shows the resultant UPGMA dendrogram of the BgIII matrix. Using an $S_{\mathrm{D}}$ cut-off value of $\mathbf{0 \cdot 6 5}$, four aggregate clusters plus two single-member clusters were recovered. Cluster 1 contains the strains isolated in Italy from tobacco and maize. The restriction fingerprint method does not allow these strains to be assigned to the four described species of Azospirillum. However, this was not surprising since these strains could not be identified using established tests (Döbereiner \& Pedrosa, 1987). Cluster 2 contains three strains of $A$. brasilense and A. lipoferum $\mathrm{SpBr} 17$. 
The $A$. brasilense strains cluster close together despite originating from different countries. Cluster 3 comprises $A$. brasilense $\mathrm{F} 14$ and two strains of $A$. lipoferum; however, one of the $A$. lipoferum strains ( $\mathrm{Col} 5$ ) joins the cluster near to the cut-off value. A clear separation between $A$. lipoferum and $A$. brasilense cannot be inferred from this study because strains belonging to these two species are mixed in clusters 2 and 3 . This was partly expected because $A$. lipoferum strains Sp242 and SpBr17 are rather atypical (Döbereiner, 1983; J. Döbereiner, personal communication), and DNA:DNA hybridization values among strains of $A$. lipoferum are low (Falk $\boldsymbol{e}$ al., 1986). Cluster 4, comprising $A$. amazonense, strains DSM 2787 and Y2, shows an $S_{\mathrm{D}}$ value lower than 0.50 with all other strains, including $A$. amazonense Y6, which formed a single-member cluster. These data support the suggestion that $A$. amazonense is heterogeneous, and distant from the other azospirilla (Falk et al., 1986; Reinhold et al., 1987; Schenk \& Werner, 1988). Strain Au5, which was the only representative of the species $A$. halopraeferens analysed, also formed a single-member cluster, although it has an $S_{\mathrm{D}}$ value of 0.64 with cluster 1 .

Our results indicate that DNA restriction pattern analysis enables bacteria of the genus Azospirillum belonging to the same or to closely related species to be differentiated. This approach may be valuable for the identification of re-isolated soil inoculants, screening of new isolates, and patenting of engineered strains.

Although few taxonomic conclusions can be drawn, our data indicate that total DNA restriction fingerprints could be used, in addition to routine identification tests, in the species attribution of isolates of Azospirillum, since, in most instances, an $S_{\mathrm{D}}$ of $\mathbf{0 . 6 5}$ separates clusters at the species level.

The authors thank Fabio Bocci for writing the computer program, Marco Bosco for photographs, Leonardo Casini for help with the SAS program, J. Döbereiner, A. Hartmann and F. Favilli for Azospirillum strains, Barbara Tullini for skilful technical assistance and Mario Polsinelli for critical discussion.

\section{References}

Allardet-Servent, A., Bourg, G., Ramuz, M., Pages, M., Bellis, M. \& RoIzEs, G. (1988). DNA polymorphism in strains of the genus Brucella. Journal of Bacteriology 170, 4603-4607.

BjoRVATN, B., Lund, V., KRistiansen, B. E., Korsnes, L., SpanNe, O. \& LINDQVIST, B. (1984). Applications of restriction endonuclease fingerprinting of chromosomal DNA of Neisseria meningitidis. Journal of Clinical Microbiology 19, 763-765.

Chowdhury, S. I., HammerschmidT, W., Ludwig, H., Thein, P. \& BUHK, H. J. (1986). Rapid method for the identification and screening of herpesviruses by DNA fingerprinting combined with blot hybridization. Journal of Virological Methods 14, 285-291.

DöbereINER, J. (1983). Ten years Azospirillum. In Azospirillum II, Genetics, Physiology, Ecology, pp. 9-23. Edited by W. Klingmüller. Basel: Birkhäuser Verlag.
DöBEREINER, J. (1987). Isolation and identification of root associated diazotrophs. In Nitrogen Fixation with Non-legumes: Proceedings of the 4th International Symposium on Nitrogen Fixation with Nonlegumes, pp. 103-108. Edited by F. A. Skinner, R. M. Boddey \& I. Fendrik. Dordrecht: Kluwer.

DöBEREINER, J. \& DAY, J. M. (1975). Associative symbiosis in tropical grasses: characterization of microorganisms and dinitrogen fixing sites. In Proceedings of the 1st International Symposium on Nitrogen Fixation, pp. 518-538. Edited by W. E. Newton \& J. C. Nyman. Pullman: Washington State University Press.

Döbereiner, J. \& Pedrosa, F. O. (1987). Nitrogen-fixing Bacteria in Nonleguminous Crop Plants, pp. 4-14. Madison: Science Tech Publishers.

DoBRITSA, S.V. (1985). Restriction analysis of the Frankia spp. genome. FEMS Microbiology Letters 29, 123-128.

FalK, E. C., Johnson, J. L., Baldani, V. L. D., Döbereiner, J. \& KRIEG, N. R. (1986). Deoxyribonucleic and ribonucleic acid homology studies of the genera Azospirillum and Conglomeromonas. International Journal of Systematic Bacteriology 36, 80-85.

Goldman, D. \& Merril, C. R. (1982). Silver staining of DNA in polyacrylamide gels: linearity and effect of fragment size. Electrophoresis 3, 24-29.

Grothues, D. \& TÜMmLeR, B. (1987). Genome analysis of Pseudomonas aeruginosa by field inversion gel electrophoresis. FEMS Microbiology Letters 48, 419-422.

HaAhtela, K., Wartiovaara, T., Sudman, V. \& Skujins, J. (1981). Root-associated $\mathrm{N}_{2}$ fixation (acetylene reduction) by Enterobacteriaceae and Azospirillum in cold climate spodsoils. Applied and Environmental Microbiology 41, 203-206.

Hood, D. W., Dow, C. S. \& GreEN, P. N. (1988). Electrophoretic comparison of total soluble proteins in the pink-pigmented facultative methylotrophs. Journal of General Microbiology 134, 2375-2383.

Hookey, J. V., Waitkins, S. A. \& Jackman, P. J. H. (1985). Numerical analysis of Leptospira DNA-restriction endonuclease patterns. FEMS Microbiology Letters 29, 185-188.

Krieg, N. R. \& Döbereiner, J. (1984). Genus Azospirillum Tarrand Krieg and Döbereiner 1979, $79^{\mathrm{AL}}$ (effective publication: Tarrand, Krieg and Döbereiner 1978, 978). In Bergey's Manual of Systematic Bacteriology, vol. 1, pp. 94-104. Edited by N. R. Krieg \& J. G. Holt. Baltimore: Williams \& Wilkins.

Kristiansen, B. E., BJoRvatN, B., Lund, V., LindQVist, B. \& Holten, E. (1985). Differentiation of B15 strains of Neisseria meningitidis by DNA restriction endonuclease fingerprinting. Journal of Infectious Diseases 150, 672-676.

LAEMMLI, U. K. (1970). Cleavage of structural proteins during the assembly of the head of bacteriophage T4. Nature, London 227, 680685.

LAMM, R. B. \& NEYRA, C. A. (1981). Characterization and cyst production of azospirilla isolated from selected grasses growing in New Jersey and New York. Canadian Journal of Microbiology 27, $1320-1325$.

Maniatis, T., Fritsch, E. F. \& SAmbrooK, J. (1982). Molecular Cloning: a Laboratory Manual. Cold Spring Harbor, NY: Cold Spring Harbor Laboratory.

Mielenz, J. R., Jackson, L. E., O'Gara, F. \& Shanmugam, K. T. (1979). Fingerprinting bacterial chromosomal DNA with restriction endonuclease EcoRI: comparison of Rhizobium spp. and identification of mutants. Canadian Journal of Microbiology 25, 803-807.

OKon, Y. (1985). Azospirillum as a potential inoculant for agriculture. Trends in Biotechnology 3, 223-229.

Peterson, E. M. \& De La Maza, L. M. (1988). Restriction endonuclease analysis of DNA from Chlamydia trachomatis biovars. Journal of Clinical Microbiology 26, 625-629.

Reinhold, B., Hurek, T., NiemanN, E.-G. \& Fendrik, I. (1985). Strain specific chemotaxis of Azospirillum spp. Journal of Bacterio$\log y$ 162, 190-195.

Reinhold, B., HUREK, T., FendRIK, I., Pot, B., Gillis, M., Kersters, K., Thielemans, S. \& De LeY, J. (1987). Azospirillum halopraeferens sp. nov., a nitrogen-fixing organism associated with roots of Kallar grass (Leptochloa fusca (L.) Kunth). International Journal of Systematic Bacteriology 37, 43-51. 
SAS InstITUTE INC. (1987). SAS/STAT TM Guide for Personal Computer. Version 6 Edition. Cary, NC: SAS Institute Inc.

SCHENK, S. U. \& WERNER, D. (1988). Fatty acid analysis of four Azospirillum species reveals three groups. Archives of Microbiology 149, 580-582.

SKare, J., Summers, W. P. \& Summers, W. C. (1975). Structures and functions of herpesvirus genomes. I. Comparison of five HSV-1 and two HSV-2 strains by cleavage of their DNA with EcoRI restriction endonuclease. Journal of Virology 15, 726-732.
Sneath, P. H. A. \& Sokal, R. R. (1973). Numerical Taxonomy. The Principles and Practices of Numerical Classification. San Francisco: W, H. Freeman.

Sorensen, B., Falk, E. S., Wisloff-Nilsen, E., Bjorvatn, B. \& KRISTIANSEN, B. E. (1985). Multivariate analysis of Neisseria DNA restriction endonuclease patterns. Journal of General Microbiology 131, 3099-3104. 